\title{
Włodzimierz Gogłoza
}

Uniwersytet Marii Curie-Skłodowskiej w Lublinie e-mail:wgogloza@poczta.umcs.lublin.pl telefon: +48 815375236

DOI: $10.15290 /$ mhi.2016.15.02.12

\section{Hayek, common law i teoria spontanicznego porządku - problemy Hayekowskiej analizy angloamerykańskiej kultury prawnej}

\begin{abstract}
SUMMARY
Hayek, common law and the theory of spontaneous order - some problems with Hayek's analysis of the Anglo-American legal tradition
\end{abstract}

The theory of spontaneous order is widely regarded as one of the most important contributions of F.A. Hayek to the development of social sciences. Hayek's main example of an emergent order is the classical (Medieval and Early Modern) common law. In his account, common law is not only a result of spontaneous evolution but also the main source of the unusual amount of freedom the early modern Englishman enjoyed compared to his European counterparts. In this paper I discuss some problems with Hayek's analysis of the historical development of common law. In particular I criticize his claim that classical common law was based around precedents, and stress the surprising given his economic views - lack of appreciation for the role competition between different courts played in the development of English law up until the nineteenth century. In conclusion I argue that polycentric legal order is the proper foundation for Hayek's "constitution of liberty".

Key words: F. A. Hayek, theory of spontaneous order, common law, evolutionary theory of law, polycentrism.

Słowa kluczowe: F. A. Hayek, ład emergentny, common law, ewolucyjna teoria prawa, policentryzm.

I. Teoria spontanicznego porządku, czy też emergentnego ładu, jak określa się ją we współczesnej literaturze przedmiotu jest uważana za jeden z największych wkładów Friedricha von Hayeka w nauki społeczne ${ }^{1}$. Jej doniosłość polega na dostarczeniu ogólnego wytłumaczenia dla fenomenu samorzutnego

Zob. np. G. P. O'Driscoll, Economics as a Coordination Problem: The Contributions of Friedrich A. Hayek, Kansas City 1977, passim; E. Butler, Hayek: His Contribution to the Political and Economic Thought of Our Time, London 1983, passim; P.J. Boettke, The Theory of Spontaneous Order and Cultural Evolution in the Social Theory of F.A. Hayek, "Cultural Dynamics" 1990, t. 3, z. 1, s. 61-81. 
kształtowania się złożonych ładów społecznych i instytucjonalnych, bez użycia mechanizmów racjonalności konstruktywistycznej, tj. przy braku świadomego planu i zorganizowanych działań zmierzających do jego realizacji.

Hayek nie był oczywiście pierwszą osobą, która poszukiwała niekonstruktywistycznego wyjaśnienia dla formowania się instytucji społecznych - norm moralnych, konwencjonalnych sposobów zachowania, prawa, pieniądza, rynku. Korzeni rozwijanej przez niego teorii można doszukiwać się w pracach wybitnych przedstawicieli szkockiego oświecenia - Mandeville'a, Hume'a, Fergusona - czy nawet w jeszcze wcześniejszych pracach hiszpańskich scholastyków ${ }^{2}$. Wkład samego Hayeka w rozwój koncepcji spontanicznego porządku polega nie na oryginalności jego uwag, lecz zastąpieniu metafor w rodzaju słynnej „niewidzialnej ręki” A. Smitha, koherentną, choć rudymentarną i niepozbawioną problemów, teorią samorzutnego kształtowania się ładu społecznego, opartą na wykorzystaniu rozproszonej wiedzy jednostek, ewolucyjną przewage grup funkcjonujących w oparciu o najbardziej efektywne konwencje społeczne i transmisję kulturową za pomocą, której normy te upowszechniają się między społecznościami ${ }^{3}$.

Idea Hayeka spotkała się z bardzo szerokim i różnorodnym odzewem. Z jednej strony stała się ona źródłem inspiracji dla dynamicznie rozwijających się teorii racjonalności ekologicznej, kompleksowych systemów dostosowawczych i samoorganizujących się oraz tzw. analitycznego anarchizmu, multidyscyplinarnego obszaru badań empirycznych nad funkcjonowaniem stanu natury i emergentnym kształtowaniem się instytucji społecznych ${ }^{4}$. Z drugiej jednakże spotkała się z licznymi głosami krytycznymi, z których - co interesujące - najbardziej radykalne wywodzą się ze środowiska, z którym Hayek był najbliżej związany, a więc przedstawicieli austriackiej szkoły w ekonomii. Ci ostatni zarzucając jego teorii antyracjonalizm, „mistyczno-kolektywistyczny charakter”, „metaekonomiczną ezoteryczność”, czy wręcz „deprecjonowanie statusu ludzkiego rozumu" ${ }^{\prime 5}$. Mniej radykalni krytycy idei ładu emergentnego zwracają uwagę na jej nadmierną ogólnikowość, bezkrytyczny tradycjonalizm Hayeka

2 N. Barry, The Tradition of Spontaneous Order, "Literature of Liberty" 1982, t. 5, z. 2, s. 7-58; S. Horowitz, From Smith to Menger to Hayek: Liberalism in the Spontaneous-Order Tradition, "The Independent Review" 2001, t. 6, z. 1, s. 81-97.

3 F.A. von Hayek, Kinds of Order in Society, "New Individualist Review” 1964, t. 3, z. 2, s. 457-466.

$4 \quad$ Zobacz odpowiednio V.L. Smith, Racjonalność w ekonomii, Warszawa 2013, passim; G. Dizerga, Outlining a New Paradigm, "Cosmos \& Taxis. Studies in Emergent Order and Organization" 2013, t.1, z. 1, s. 3-19; W. Gogłoza, Analityczny anarchizm - cele, przedmiot i metody badań empirycznych nad stanami natury, [w:] Myślenie o polityce i prawie - przedmiot, metoda, perspektywa, red. Barwicka-Tylek, A. Czarnecka, M. Jaskólski, J. Malczewski, Warszawa 2015, s. 209-232.

$5 \quad$ Zob. J.T. Salerno, Ludwig von Mises as Social Rationalist, "The Review of Austrian Economics" 1990, t. 4, z. 1, s. 26-54; H.H. Hoppe, F.A. Hayek on Government and Social Evolution: A Critique, "The Review of Austrian Economics" 1994, t. 7, z. 1, s. 67-93; M.N. Rothbard, The Present State of Austrian Economics, “Journal des Economistes et des Etudes Humaines" 1995, t. 6, z. 1, s. 43-89. 
oraz napięcie między liberalizmem jego normatywnych postulatów a konserwatyzmem wydającym się być konsekwencją jego pozytywnych analiz ${ }^{6}$.

Celem mojego artykułu nie jest jednak podjęcie rozważań nad zasadnością teorii spontanicznego porządku, lecz analiza uwag Hayeka dotyczących wczesnonowożytnego common law jako systemu prawnego o emergentnym charakterze, który może stanowić liberalną alternatywę dla systemów prawa stanowionego. Zamierzam w nim wykazać, iż zarówno pozytywna, jak i normatywna strona prowadzonych przez niego rozważań jest problematyczna. W szczególności będę starał się udowodnić, że Hayek błędnie przypisał klasycznemu common law cechę prawa precedensowego i całkowicie pominął zakres konkurencji istniejącej między sądami różnych jurysdykcji we wczesnonowożytnej Anglii. Konkluzją artykułu będzie wskazanie, iż zarówno na gruncie przyjętych przez Hayeka założeń, jak i w świetle historycznych analiz, jego „konstytucja wolności" powinna mieć policentryczny charakter.

II. Punktem wyjścia dla rozważań Hayeka jest wprowadzenie wyraźnego rozróżnienia pomiędzy prawem (nomos), czyli podlegającym egzekucji normom postępowania a legislacją (thesis), to jest celowym tworzeniem wiążących reguł zachowania mającym prowadzić do osiągnięcia określonego rezultatu. W przeciwieństwie do legislacji, która jest produktem konstruktywistycznej racjonalności i pojawiła się bardzo późno w procesie rozwoju społecznego, prawo „nie zostało nigdy wynalezione” i ma charakter odwieczny - towarzyszyło ludzkości na długo przed tym zanim była ona w stanie je wyartykułować za pomocą języka ${ }^{7}$. Normy rządzące wzajemnymi relacjami jednostek są niezależne od woli pojedynczych osób. Powstają nie w drodze świadomych decyzji konkretnych podmiotów, lecz jako superweniencja powtarzalnych interakcji wielu ludzi i upowszechniania się wśród nich zachowań, które minimalizują konflikty.

Na gruncie założeń przyjętych przez Hayeka, prawo jest pierwotne wobec zbiorowości ludzkich i wszelkich tworzonych przeze nie instytucji. Jak stwierdza, to nie społeczeństwo tworzy normy, to podzielanie norm przez jednostki tworzy społeczeństwo ${ }^{8}$. Thesis, czyli świadomie kreowane reguły postępowania mogą jedynie uzupełniać konwencje społeczne i dodatkowo zabezpieczać ich przestrzeganie, ale nie mogą ich całkowicie zastąpić ani wyeliminować. Stąd też zdaniem Hayeka powszechny we współczesnej teorii i doktrynie prawa sposób ustalania hierarchii obowiązujących norm, zgodnie z którym na szczycie systemu prawnego znajduje się konstytucja, dalej ustawy i akty niższego rzędu, na samym zaś dole lokowane są normy o charakterze zwyczajowym - choć logicz-

Zob. np. T. Sandefur, Some Problems with Spontaneous Order, "The Independent Review" 2009, t. 14, z. 1, s. 5-25; D. R. Steele, Hayek's Theory of Cultural Grup Selection, "The Journal of Libertarian Studies" 1987 , t. 8, z. 2, s. 171-195.

$7 \quad$ F.A. von Hayek, Law, Legislation and Liberty. A New Statement of the Liberal Principles of Justice and Political Economy, t. 1, London 1998, s. 72.

8 Ibidem, t. 3, s. 33. 
ny i uzasadniony wymogami stosowania prawa - stawia porządek społeczny na głowie. „Do norm, które zwykliśmy określać mianem «prawa», a które są normami organizacji nie zaś sprawiedliwego postępowania, [w powszechnej opinii] zaliczają się w pierwszej kolejności wszystkie reguły określające alokacje i ograniczenia władzy publicznej składające się na prawo konstytucyjne. Są one zwyczajowo postrzegane jako «najwyższy» rodzaj prawa, któremu należy się szczególne uznanie, bądź też któremu jesteśmy obowiązani okazywać większy szacunek, niż innym rodzajom prawa. Pomimo jednak istnienia historycznych powodów uzasadniających takie podejście, bardziej zasadnym byłoby postrzeganie tych norm raczej jako superstruktury wzniesionej dla egzekwowania prawa, niż - jak to zwykle bywa - źródła wszelkiego innego obowiązującego prawa"'

Pierwotny i emergentny charakter nomos sprawia, zdaniem Hayeka, iż prawo nie podlega tworzeniu - normy prawne można jedynie odkrywać i artykułować analizując zachowania społeczne i ustalając przyczyny konfliktów, do jakich dochodzi w obrębie danej społeczności. Z tego też względu jurysprudencja winna być zarazem nauką empiryczną, jak i eksperymentalną. Empiryczną, albowiem zadaniem sędziego rozstrzygającego spór, jest odtworzenie obowiązujących w danym społeczeństwie oczekiwań, którymi powinny się kierować strony w swych wzajemnych relacjach i wydanie na tej podstawie orzeczenia, które będzie służyło porządkowi zbudowanemu na pokojowych relacjach jednostek ${ }^{10}$. Eksperymentalną, ponieważ odkrywanie norm obowiązujących w społeczności z konieczności odbywa się na drodze prób i błędów. Z uwagi na złożoność życia społecznego sędzia wydający orzeczenie nie jest w stanie przewidzieć wszystkich konsekwencji swojego rozstrzygnięcia. Ex post może się więc okazać, iż podjęta przez niego decyzja zamiast eliminować spory, eskaluje je lub prowadzi do powstawania nowych. Normy prawne nie funkcjonują bowiem w próżni i są jednym z wielu czynników determinujących zachowania jednostek. Nie da się jednak inaczej ustalić rzeczywistego wpływu danej normy na funkcjonowanie porządku społecznego jak tylko poprzez jej artykulację i egzekucję. Część decyzji sędziów z całą pewnością okaże się być niekorzystna dla funkcjonowania porządku społecznego. Efektywność systemu prawnego wyrosłego na gruncie orzecznictwa polega jednak na tym, iż pojedyncza błędna decyzja sędziego ma niewielkie szanse na stanie się obowiązującą regułą ${ }^{11}$.

Zdaniem Hayeka postrzeganie prawa jako wyrazu odwiecznego porządku, niezależnego od ludzkiej woli, który podlega jedynie odkrywaniu, nie zaś tworzeniu, było powszechne wśród ludzi wszystkich nacji, z wyjątkiem obszaru helleńskiego, aż do czasu średniowiecza ${ }^{12}$. Około XIII w., w kulturze

Ibidem, t. 1, s. 134 .

Ibidem, s. 86 .

R. Barnett, The Structure of Liberty. Justice and the Rule of Law, Oxford 2000, s. 124.

12 F.A. Hayek, Law, Legistation..., t. 1, s. 81-83. 
okcydentalnej, wraz z postępującym procesem umacniania się władzy monarszej, prawo zaczęło być jednak postrzegane jako instrument władcy - akt świadomej i nieograniczonej woli osoby dzierżącej tron. Wówczas to, jak twierdzi Hayek, legislacja do tej pory ograniczająca się do kwestii organizowania i kierowania aparatem wykonawczym, stała się narzędziem konstruowania porządku społecznego. Proces ten $\mathrm{z}$ różnym nasileniem dotyczył wszystkich zachodnich społeczeństw, w najmniejszym stopniu dotknął jednak Anglii, kraju, w którym jeszcze kilka wieków po zmierzchu średniowiecza, władza prawodawcza odgrywała stosunkowo niewielkie znaczenie. Powodem, dla którego Anglia tak długo skutecznie opierała się przed legislacją było zdaniem Hayeka istnienie w społeczeństwie „głęboko zakorzenionej tradycji common law, prawa postrzeganego nie jako produkt czyjejkolwiek woli, ale bariery dla wszelkiej władzy, włącznie z tą należącą do króla - tradycji którą Sir Edward Coke bronił przez Królem James I i jego kanclerzem Sir Francis Baconem, i którą Sir Matthew Hale genialnie wyłożył pod koniec XVII w. w opozycji do Thomasa Hobbesa"13.

Dla Hayeka klasyczne, wczesnonowożytne angielskie common law, opisywane w pracach Coke'a (1552-1634), Hale'a (1609-1676), czy Sir Johna Daviesa (1597-1621), jest egzemplifikacją spontanicznego porządku na gruncie prawnym. Nie powstało ono w drodze świadomych działań prawodawcy realizującego określone cele społeczne, lecz długotrwałego, ewolucyjnego procesu, rozstrzygania partykularnych sporów skonfliktowanych stron, opartego na konwencjonalnych regułach postępowania obowiązujących w danej społeczności.

W teorii prawa Hayeka można dojrzeć wyraźną analogię między działaniami sędziów rozstrzygających spory w systemie common law i przedsiębiorców funkcjonujących na wolnokonkurencyjnym rynku ${ }^{14}$. W swoich pracach ekonomicznych podkreśla on, iż przedsiębiorczość jest w dużej mierze opartym na metodzie prób i błędów procesem zdobywania już istniejącej, ale jeszcze niewyartykułowanej, gdyż rozproszonej wśród wielu uczestników rynku, wie$\mathrm{dzy}^{15}$. Właściciel sklepu nie tworzy cen, a jedynie „eksperymentalnie” próbuje określić, jaką cenę są skłonne zaakceptować inne podmioty na rynku. Podobnie zdaniem Hayeka sędzia nie tworzy prawa - odkrywa jedynie już istniejące w danej społeczności reguły, których naruszenie doprowadziło do powstania konfliktu między stronami. Stąd też, tak jak cena produktu nie jest wyrazem decyzji jednej osoby, lecz odbiciem zachowań bardzo dużej liczby podmiotów, często niemających ze sobą żadnej styczności, tak też rozstrzygnięcie sędziego

Ibidem, s. 84-85.

14 G. B. Christiansen, Law as a Discovery Procedure, "Cato Journal" 1990, t. 9, z. 3, s. 497-530; T. J. Zywicki, A. B. Sanders, Posner, Hayek, and the Economic Analysis of Law, "Iowa Law Review" 2008, z. 93, s. 559-604.

15 F. A. Hayek, The Use of Knowledge in Society, "American Economic Review" 1945, t. 35, z. 4, s. 519-530. Przystępne omówienie tego zagadnienia można znaleźć w D. J. Boudreaux, The Essential Hayek, Vancouver 2014, s. 17-23. 
nie jest jednostkową decyzją, ale odzwierciedleniem konwencjonalnych zachowań członków danej społeczności.

Zdaniem Hayeka, kluczową rolę w procesie odkrywania prawa przez sędziów odgrywa w systemie common law zasada stare decisis. Opierając swoje rozstrzygnięcie na precedensach wyprowadzają oni na gruncie wcześniejszych orzeczeń zapadłych $\mathrm{w}$ podobnych sprawach generalne zasady postępowania, które następnie stosują do rozstrzygnięcia trafiających przed nich sporów. Za sprawą konsekwentnego stosowania się do zasady precedensów common law nie jest prostą sumą rozstrzygnięć partykularnych sporów, lecz systemem generalno-abstrakcyjnych norm, dla których indywidualne orzeczenia stanowią jedynie ilustrację $e^{16}$

Fakt, iż w systemie common law normy są odkrywane i artykułowane wyłącznie w sytuacji zaistnienia sporu między jednostkami ma, zdaniem Hayeka, bardzo istotne konsekwencje dla zakresu wolności, jakim cieszą się osoby poddane temu systemowi. Oznacza on bowiem, iż prawo jest zainteresowane jedynie tymi działaniami, które wpływają na innych w sposób, którego ci sobie nie życzą. Zachowania, które nie mają takiego charakteru, jak np. te podejmowane samodzielnie $\mathrm{w}$ zaciszu domowych ścian, bądź też dobrowolne przedsięwzięcia kilku osób niemające negatywnych konsekwencji dla osób trzecich, nie podlegają jurysdykcji sądów ${ }^{17}$. Stąd też wszystkie działania, bądź też zaniechania, które nie wyrządzają identyfikowalnej krzywdy lub szkody osobom trzecim muszą być uznawane na gruncie prawnym za dozwolone (co jest niezależne od ich oceny moralnej) ${ }^{18}$.

To domniemanie swobody niekonfliktowego działania, w tym zwłaszcza zawierania dobrowolnych umów, jest zdaniem Hayeka kluczową cechą common law i źródłem jego przewagi nad systemem prawa stanowionego. Wyjątkowy zakres wolności jaką cieszyli się wczesnonowożytni Anglicy na tle innych ówczesnych narodów, nie był wynikiem separacji władzy prawodawczej i wykonawczej, jak utrzymywał np. Monteskiusz, lecz faktu, iż prawo rządzące zachowaniami jednostek wyrosło nie na gruncie legislacji, lecz orzeczeń niezależnych od władzy publicznej sądów, interweniujących wyłącznie w sytuacjach zaistnienia konfliktów, których strony nie były w stanie rozstrzygnąć samodzielnie ${ }^{19}$.

Hayek nie był przy tym bezkrytycznym zwolennikiem klasycznego common law. Jako potencjalnie problematyczną wskazuje on zwłaszcza silną tendencję tego systemu do rozwoju wyłącznie $w$ jednym kierunku. Za sprawą stosowania przez angielskie sądy reguły stare decisis sędziom trudno jest zawrócić z raz obranej ścieżki orzeczniczej, nawet jeśli ex post okaże się, iż przyjęta we

$16 \quad$ F. A. Hayek, Law, Legislation..., t. 1, s. 86.

17 Ibidem, s. 101.

18 Zob. zwł. wstęp F. A. Hayeka do W. Block, Defending the Undefendable. The Pimp, Prostitute, Scab, Slumlord, Libeler, Moneylender, and Other Scapegoats in the Rogue's Gallery of American Society, Auburn 2008, s. XII.

19 F. A. Hayek, Law, Legislation..., t. 1, s. 85. 
wcześniejszych rozstrzygnięciach reguła prowadzi do podejmowania decyzji o niekorzystnych konsekwencjach społecznych ${ }^{20}$. W takiej sytuacji, jego zdaniem, niezbędna może się okazać korygująca interwencja legislatury, która w przeciwieństwie do sędziów ma możliwość nawet radykalnego zerwania z utrwaloną linią orzeczniczą. Podkreśla on przy tym, iż tego rodzaju działania powinny mieć wyjątkowy charakter. Zastąpienie norm wyrosłych na gruncie orzeczeń sądów, decyzją ciała prawodawczego jest według niego dopuszczalne jedynie w sytuacji, gdy o kierunku rozwoju orzecznictwa zdecydowały przeszłe błędy popełnione przez sędziów, lub gdy za sprawą postępującego rozwoju społecznego dalsze podążanie za precedensami doprowadziłoby do powstania konsekwencji powszechnie uznawanych za niesprawiedliwe. Za szczególnie częsty w praktyce powód niekorzystnego rozwoju orzecznictwa uznaje on przy tym zdominowanie środowiska sędziowskiego przez grupy społeczne, których interesy nie pokrywają się z interesami ogółu. Przykładem mogą być w tym względzie takie obszary prawa, jak relacje między panami a służbą, właścicielami i najemcami, wierzycielami i dłużnikami, czy przedsiębiorstwami i klientami. W obrębie każdej z tych relacji prawo rozwijało się przez bardzo długi czas tak, by chronić interesy jednej tylko strony - tej, spośród której rekrutowali się w większości sędziowie. „Tego rodzaju sytuacje, w których okaże się, iż dotychczas akceptowane normy, muszą zostać uznane za niesprawiedliwe w świetle bardziej ogólnych zasad sprawiedliwości mogą wymagać rewizji nie tylko pojedynczych orzeczeń, ale całych gałęzi utrwalonej linii orzeczniczej. Cel ten zaś nie może zostać osiągnięty na gruncie pojedynczych decyzji sądów podjętych $\mathrm{w}$ świetle istniejących norm precedensowych"21.

III. Powyższe tezy Hayeka są wielce problematyczne, zarówno w odniesieniu do przeprowadzonych przez niego pozytywnych analiz, jak i wyprowadzanych na ich gruncie normatywnych postulatów. Odwołując się do klasycznego common law funkcjonującego w Anglii przed umocnieniem się władzy ustawodawczej, przypisuje on temu systemowi dwie cechy współczesnego common law, które nie występowały w nim w okresie wczesnonowożytnym, tj. obowiązywanie zasady stare decisis oraz monocentryczny charakter systemu sądowniczego. Zabieg ten jest nie tylko błędny historycznie, ale ma bardzo daleko idące konsekwencje dla oceny twierdzenia Hayeka, jakoby prawo precedensowe stanowiło liberalną alternatywę dla systemu prawa stanowionego.

Hayek twierdzi, iż klasyczne common law zawdzięczało swój generalno-abstrakcyjny charakter obowiązywaniu zasady (doktryny) stare decisis, zgodnie z którą sądy są związane sposobem, w jaki wcześniej zostały rozstrzygnięte spory podobne do aktualnie rozpatrywanych przez nie spraw. Problem $z$ tą tezą Hayeka polega na tym, iż doktryna precedensu wykształciła się bardzo późno

$20 \quad$ Ibidem, s. 88.

21 Ibidem, s. 89. 
$\mathrm{w}$ procesie historycznego rozwoju common law. Jej początki datuje się zazwyczaj na przełom XVII i XVIII w., a w swej współczesnej, „rygorystycznej formie” której autor Law Legislation, Liberty poświęca najwięcej uwagi - obowiązuje ona dopiero od XIX w., a więc długo po zmierzchu okresu klasycznego ${ }^{22}$.

Pierwsi angielscy komentatorzy, tacy jak anonimowy autor powstałego około 1290 r. traktatu znanego jako Fleta bądź to w ogóle nie powoływali się w swych pracach na orzeczenia, bądź też jak Henry de Bracton w De Legibus et Consuetudinibus Angliae (c. 1235), przywoływali w celu wskazania na wykształcenie się $\mathrm{w}$ praktyce sądowej zwyczajowego sposobu rozstrzygania określonego rodzaju sporów. Także w późnośredniowiecznym i wczesnonowożytnym orzecznictwie niewiele jest przykładów odwoływania się przez sędziów do wcześniejszych wyroków, a jeśli już one się pojawiają, to dla powołania się na istniejący wśród sędziów zwyczaj, tzw. mos iudicorum ${ }^{23}$. Stąd też jeszcze w pierwszej połowie XVII w. Sir John Davies twierdził, iż common law jest niczym innym, jak tylko systemem niepisanego prawa zwyczajowego, w którym za obowiązujące uznaje się jedynie te normy, które obronną ręką wyszły z całego szeregu prób, jakim poddał je upływ czasu. „Zwyczaj nigdy nie staje się Prawem, które wiąże ludzi, dopóki nie został wypróbowany i zaakceptowany raz po raz na przestrzeni niepamiętnych czasów, w ciągu których nie powstała w związku z nim żadna niedogodność, jeśli bowiem kiedykolwiek w przeszłości zostałby uznany za niedogodny, przestałby być stosowany, zostałby zerwany i w konsekwencji utraciłby cnotę i moc jaką ma Prawo"24.

Także sam termin „precedens" (początkowo w j. ang. pisany jako president) ma stosunkowo "młody" rodowód. Jego pierwsze udokumentowane użycie ma miejsce dopiero w 1557 r. i nastąpiło w wyroku, w którym sąd orzekł „wbrew dwóm precedensom" (notwithstanding two presidents) ${ }^{25}$. Na przełomie XVI i XVII w. liczba precedensów zidentyfikowanych w orzeczeniach wyraźnie wzrasta, ale w większości przypadków odnoszą się one wyłącznie do kwestii proceduralnych. Znamienny jest również fakt, iż w najstarszych znanych nam angielskich orzeczeniach odwołujących się do wcześniejszych wyroków, brak jest kluczowego dla współczesnego rozumienia doktryny stare decisis rozróżnienia na ratio decidendi i obiter dicta. Prawdopodobnie pierwszym sędzią, który podnosi tą kwestię jest Sir John Vaughn, który w 1673 r. w wyroku King's Bench w sprawie Bole v. Horton podkreślił, iż „opinia wygłoszona w sądzie, jeśli nie jest niezbędna dla rozstrzygnięcia, nie jest opinią sądową, ani czymś więcej niż

22 T. F. T. Plucknett, A Concise History of the Common Law, Indianapolis 2010, s. 342-350 oraz D. Vong, Biding Precedent and English Judicial Law-Making, "Jura Falconis" 1984-1985, t. 21, z. 3, s. 318-346.

23 H. Berman, The Origins of Historical Jurisprudence: Coke, Selden, Hale, "The Yale Law Journal" 1994, t. 103, z. 7, s. 1732.

24 J. Davis niepaginowany wstęp do Irish Reports, London 1674. Przytaczam za J. G. A. Pocock, The Ancient Constitution and the Feudal Law: A Study of English Historical Thought in the Seventeenth Century, Cambridge 1987, s. 32-33.

25 T. F. T. Plucknett, op. cit., s. 348. 


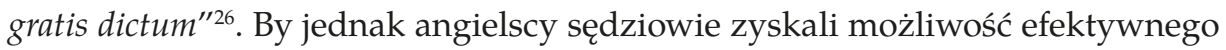
ustalania tego, co we wcześniejszych orzeczeniach stanowiła ratio, a co dictum musiał minąć kolejny wiek. Dopiero bowiem w drugiej połowie XVIII w. pojawiły się pierwsze względnie powszechnie dostępne, aktualne i co najważniejsze wiarygodne zbiory orzeczeń sądowych. Bez nich odwoływanie się przez sędziów do wcześniejszych precedensowych rozstrzygnięć stanowiło bardzo duże wyzwanie praktyczne ${ }^{27}$.

Przed upowszechnieniem się na Wyspach Brytyjskich pierwszych maszyn drukarskich jedynym wiarygodnym źródłem wiedzy na temat wyroków wydanych przez angielskie sądy były tzw. plea rolls ${ }^{28}$. Były to ręcznie spisane papierowe zwoje zawierające informacje na temat merytorycznego rozstrzygnięcia danej sprawy. Zwoje te były jednakże bardzo lakoniczne - rzadko zawierały jakiekolwiek dane ponad formułę rozstrzygnięcia, nieporęczne, ciężkie (osiągały wagę nawet kilkudziesięciu kilogramów), pozbawione skorowidza i nie podlegały publikacji, stąd też miały one znikomą wartość praktyczną dla sędziów i innych prawników.

W XVI w. zaczęły się w Anglii upowszechniać drukowane zbiory orzeczeń zwane Year Books. Jakkolwiek były one łatwiej dostępne i zawierały znacznie więcej informacji niż plea rolls, podobnie jak zwoje, miały one niewielkie znaczenie w praktyce orzeczniczej. Głównym powodem takiego stanu rzeczy, był fakt, iż sporządzano je przede wszystkim na potrzeby związane z nauczaniem prawa w Inns of Court. Nie traktowano ich jako autorytatywnych źródeł wiedzy o rozstrzygnięciach sądowych, lecz materiał dydaktyczny odnoszący się do kwestii procedury sądowej, taktyki obrończej, argumentacji prawniczych. Jako spisy prywatne, w większości będące najprawdopodobniej dziełem studentów, cieszyły się one też bardzo ograniczonym autorytetem.

Za pierwszy wiarygodny zbiór orzeczeń uznawane są opublikowane pod koniec XVI w. The Commentaries Edmunda Plowdena. Mimo bardzo dużego uznania z jakim spotkało się to dzieło wśród współczesnych mu prawników nie wydaje sięjednak, by wywarło ono istotny wpływ na ówczesną praktykę orzeczniczą. Zdaniem historyków prawa dopiero publikacja na początku XVII w. serii raportów Edwarda Coke’a umożliwiła rozwój doktryny precedensu ${ }^{29}$, zaś jej współczesna rygorystyczna wersja zaczęła się kształtować pod koniec XVIII w. za sprawą pojawienia się pierwszych spisywanych na bieżąco i autoryzowanych przez sędziów zbiorów orzeczeń, dla których wzorcem stał się Reports of cases adjudged in the Court of King's Bench Sir Jamesa Burrow'a (sekretarza Lorda Mansfielda), opublikowana w pięciu tomach na przełomie lat 1778-1785.

124 Eng. Rep. 1113, 1124 (K.B. 1673).

27 J.H. Baker, The Common Law Tradition: Lawyers, Books and the Law, London 2000, passim.

28 M. Bryan, Early English Law Reporting, “University of Melburn Collections” 2009, z. 4, s. 45-50.

29 H. Berman, The Origins..., s. 1733. 
Uwagi Hayeka jakoby, klasyczne, wczesnonowożytne common law było prawem precedensowym mają zatem anachroniczny charakter. W świetle dostępnych nam źródeł dalece bardziej zasadne wydaje się być ujmowanie tego systemu w kategoriach prawa zwyczajowego kształtującego się na gruncie orzecznictwa sądowego ${ }^{30}$. Spostrzeżenie to jest bardzo istotne dla oceny normatywnych postulatów Hayeka, albowiem jak wykazują badania prowadzone na gruncie ekonomicznej analizy prawa, doktryna precedensu, którą błędnie uznawał on za fundamentalną cechę klasycznego common law prowadzi często do efektów dalece odmiennych od tych, które wydają mu się pożądane i które przypisuje on temu systemowi.

Szczególnie radykalne są $\mathrm{w}$ tym względzie wnioski wynikające $\mathrm{z}$ analiz przeprowadzonych przez jednego z najwybitniejszych przedstawicieli szkoły law and economics, współtwórcę teorii publicznego wyboru Gordona Tullocka. W swej głośnej pracy The Case Against the Common Law, Tullock dowodzi, iż współczesny angloamerykański system prawa precedensowego wbrew twierdzeniom jego liberalnych (w sensie doktrynalnym) zwolenników jest niczym innym jak tylko „socjalistyczną biurokracją" - systemem pogoni za rentą ${ }^{31}$, w którym reprezentanci procesowi stron „lobbują" sędziów za korzystnymi dla ich klientów rozwiązaniami. W takim ujęciu proces sądowy w systemie common law to gra o sumie zerowej, a strony i powoływani przez nie świadkowie są grupami nacisku próbującymi wpływać na sąd dysponujący władzą do dokonywania transferu dóbr z wykorzystaniem mechanizmów władzy publicznej (przyznawania renty). „Niewidzialna ręka ustępuje tutaj ciężkiemu butowi sędziego oraz kościstym kolanom i łokciom, na wpół ociemniałych i intelektualnie ociężałych ławników"32. Jeśli proces ten różni się czymś od zabiegów zorganizowanych grup nacisku dochodzących swych interesów przed władzą ustawodawczą to tym, że parlamentarzyści obecnej kadencji nie są w stanie związać swymi decyzjami parlamentarzystów przyszłych kadencji, podczas gdy za sprawą współczesnego rozumienia doktryny stare decisis, wyroki sędziów sądów wyższych instancji będą wiążące dla wszystkich sądów niższych instancji rozpatrujących $\mathrm{w}$ przyszłości podobne sprawy. $\mathrm{Z}$ tego też względu wartość sprzyjającego danemu podmiotowi rozstrzygnięcia sądu wyższej instancji może być dla niego większa, niż podobnej regulacji wprowadzonej na drodze ustawowej - zmiana składu ciała prawodawczego, może wszak doprowadzić do zmiany samej regulacji. W konsekwencji system ten jest potencjalnie jeszcze bardziej sprzyjający

30 J. Hasnas, Hayek, the Common Law, and Fluid Drive, "New York University Journal of Law and Liberty" 2005 , t. 1, z. 1, s. 89-98.

31 Na temat pogoni za rentą (rent-seeking) zob. S. Sztaba, Aktywne poszukiwanie renty. Teoria, przykłady historyczne, przejawy w polskiej gospodarce, Warszawa 2002.

32 G. Tullock, The Case Against the Common Law, [w:] The Selected Works of Gordon Tullock: Law and Economics, red. C. K. Rowley, t. 9, Indianapolis 2005, s. 451. 
zorganizowanym grupom interesu niż systemy prawa stanowionego ${ }^{33}$. Z tego też właśnie względu współczesne common law jest zdaniem Tullocka tak dalece nieefektywne ekonomicznie, iż jego trwanie może być uzasadniane jedynie zjawiskiem zależności od szlaku (path dependency) oraz interesami doskonale zorganizowanej grupy nacisku jaką są prawnicy.

Jakkolwiek nie ma chyba żadnego autora, który zgadzałby się z całokształtem zarysowanych wyżej poglądów Tullocka ${ }^{34}$, jego konkluzja jakoby współczesny system prawa precedensowego był mniej efektywny, niż klasyczne common law znajduje wielu zwolenników wśród przedstawicieli ekonomicznej analizy prawa. Przy czym, co istotne dla prowadzonych w niniejszej pracy rozważań, za jedną z głównych przyczyn „upadku efektywności” common law uznają oni właśnie ukształtowanie się w XIX w. rygorystycznie pojmowanej zasady precedensu. Jak stwierdza Todd Zywicki, „przed akceptacją rygorystycznej wersji doktryny stare decisis, pozyskanie przez stronę sprzyjającego orzeczenia sądu, miało dla niej minimalną wartość [na przyszłość]. Ponieważ orzeczenie w tej sprawie nie było wiążące dla innych sadów rozstrzygających później podobne spory, każde precedensowe rozstrzygnięcie miało niewielkie długoterminowe znaczenie dla stron. (...) Co więcej, elastyczność [systemu orzeczniczego] otwierała możliwość dla jego samo-korygowania się albowiem błędne bądź nieefektywne decyzje mogły być zmienione niskim kosztem przez kolejne sądy. Tam gdzie nie obowiązuje zasada stare decisis, nie ma też bodźców do angażowania się w procesy mające na celu dochodzenie renty, nie istnieje bowiem jeden podmiot upoważniony do «tworzenia» prawa. Każda doktryna prawna powstała wskutek dochodzenia renty, może być zburzona przez kolejnego sędziego, dostrzegającego jej sprzeczność z wymogami racjonalności, społecznego konsensusu i oczekiwaniami społecznymi. Pozyskanie korzystnego precedensu w systemie stare decisis zwiększa wartość przepływu dóbr wygenerowanych przez ten precedens. W rzeczy samej, istnienie zasady stare decisis stwarza bodźce dla grup interesu od podjęcia starań zmierzających do określania, które sprawy jako pierwsze trafią do sądu i które w związku z tym wyznaczą wiążący precedens na przyszłość"35. Doktryna precedensu nie tylko zatem nie występowała w klasycznym, wczesnonowożytnym common law, w którym Hayek upatruje liberalnej alternatywy dla prawa stanowionego, ale też jest czynnikiem sprawiającym, iż współczesne angloamerykańskie prawo (przynajmniej w teorii) jest co najmniej równie podatne na naciski zorganizowanych grup interesu, jak systemy, w których prawo tworzone jest na drodze legislacji.

33 „Potencjalnie”, gdyż inne czynniki mogą ograniczać zakres/wielkość transferów, zob. T. J. Zywicki, The Rise and Fall of Efficiency in the Common Law: A Supply-Side Analysis, "George Mason University Law and Economics Working Paper Series" n. 02-21, s. 9-10.

34 Na temat recepcji poglądów Tullocka w doktrynie prawa zob. idem, Spontaneous Order and the Common law: Gordon Tullock's Critique, "Public Choice" 2008, z. 135, s. 35-53.

35 Idem, The Rise and Fall..., s. 28-29. 
Problemy historycznej analizy Hayeka nie wyczerpują się jednak w przypisywaniu common law cech prawa precedensowego, nie uwzględnił on bowiem $\mathrm{w}$ swych analizach jednego $\mathrm{z}$ najważniejszych czynników w rozwoju angielskiego prawa, jakim aż do XIX w. była konkurencja między sądami różnych jurysdykcji.

W klasycznym okresie rozwoju common law w Anglii współistniał cały szereg sądów o de iure odmiennych, a zarazem de facto krzyżujących się jurysdykcjach. Sądów królewskich było siedem - Court of Common Pleas, Court of King's Bench, Court of Exchequer, Court of General Eyres, Commissions of Assize, Oyer and Terminer oraz Gaol Delivery - a obok nich funkcjonowały jeszcze liczne niezależne sądy eklezjalne, dworskie, lokalne, targowe, kupieckie oraz dwa sądy uniwersyteckie (Cambridge i Oxford). Sądy te nie tylko różniły się pod względem obowiązującej przed nimi procedury, ale i stosowanymi przez nie normami materialnymi. Obok norm common law we wczesnonowożytnej Anglii przy rozstrzyganiu sporów kierowano się m.in. normami equity, prawa kanonicznego, kupieckiego (lex mercatoria), lokalnego prawa zwyczajowego, a na terenie uniwersytetów Oxford i Cambridge także prawa rzymskiego ${ }^{36}$.

Teoretycznie sądy te miały ściśle określoną właściwość rzeczową, w praktyce jednak za sprawą różnych kreatywnych zabiegów prawnych starały się poszerzyć ją tak, by objąć swoją jurysdykcją jak największą liczbę spraw. Dla przykła$\mathrm{du}$, angielskie sądy eklezjalne regularnie rozpatrywały spory dotyczące zobowiązań umownych uznając się za właściwe we wszystkich sprawach, w których składano przysięgi na wiarę (w okresie średniowiecznym i wczesnonowożytnym wzajemne przyrzekanie na Biblię przez strony wypełnienia zobowiązania było standardową praktyką) i orzekając $\mathrm{w}$ nich jako karę pokutę obejmującą wypłatę poszkodowanej stronie odszkodowania. Podobnie Court of Exchequer de iure będący sądem właściwym wyłącznie $\mathrm{w}$ sprawach dotyczących długów wobec korony chętnie przyjmowały do rozstrzygnięcia spory majątkowe pomiędzy osobami prywatnymi, uzasadniając tą praktykę domniemaniem, iż brak właściwej reakcji mógłby doprowadzić jedną ze stron do niemożności wywiązania się z jej obowiązków finansowych względem króla. W efekcie tego rodzaju kreatywnych wybiegów prawnych, ta sama kategoria spraw mogła być rozstrzygana przez różne sądy, przy zastosowaniu odmiennych norm materialnych i proceduralnych ${ }^{37}$.

Wśród wielu powodów dla poszerzania jurysdykcji przez angielskie sądy jednym z najistotniejszych wydaje się być fakt, iż orzekający w nich sędziowie utrzymywali się aż do XIX w. głównie z opłat sądowych. Stałe pensje mieli zapewnione wyłącznie sędziowie sądów królewskich (od 1268 r.), ale nawet im

36 D. Klerman, Jurisdictional Competition and the Evolution of the Common Law, "University of Chicago Law Review" 2007, t. 74, z.4, s. 1179-1226.

37 T. J. Zywicki, The Rise and Fall..., s. 33-36. 
wynagrodzenia wypłacano nieregularnie i często z kilkuletnim opóźnieniem ${ }^{38}$. Pozostali sędziowie mogli liczyć wyłącznie na środki uzyskane od stron postępowania. Zarobki angielskich sędziów były więc nierozerwalnie związane z liczbą rozpatrywanych przez nich spraw. $Z$ tego też względu nie tylko nie mieli oni powodów, by odmawiać rozpoznania spraw nieznajdujących się de iure w ich właściwości rzeczowej, ale wręcz podlegali silnemu bodźcowi ekonomicznemu do kreowania fikcji prawnych umożliwiających im wkraczanie na obszar jurysdykcji innych sądów. W konsekwencji upowszechnienia się tych zabiegów wczesnonowożytny system prawny Anglii nabrał policentrycznego charakteru, a konkurencja istniejąca między angielskimi sądami zyskała stricte rynkowy wymiar ${ }^{39}$.

Jedną z pierwszych osób, która dostrzegła konsekwencje tego stanu rzeczy był wielki ideowy poprzednik Hayeka Adam Smith. W swej słynnej rozprawie Badania nad natura i przyczynami bogactwa narodów (1776) ten wybitny przedstawiciel szkockiego oświecenia dowodził, iż "doskonałość angielskich sądów” była efektem współzawodnictwa pomiędzy sędziami różnych sądów, z których każdy dążył do tego, aby sąd, w którego składzie zasiadał, ,znalazł jak najszybszy i najbardziej skuteczny, a zgodny z prawem sposób na to, by zaradzić wszelkiej niesprawiedliwości"40. Współcześni badacze tego zagadnienia zgadzają się ze Smithem podkreślając, iż konkurencja była nie tylko swoistym spiritus movens dla rozwoju angielskiego prawa, ale i głównym czynnikiem determinującym jego efektywność w okresie wczesnonowożytnym ${ }^{41}$. Tam bowiem, gdzie strony mogą niemal zupełnie swobodnie wybierać pomiędzy wieloma konkurencyjnymi sądami, żaden $\mathrm{z}$ nich nie może pozwolić sobie na wydawanie rozstrzygnięć, które byłyby korzystne wyłącznie dla jednej kategorii stron. Przy braku wyłącznej właściwości rzeczowej i niemożności narzucania swej jurysdykcji przez sądy, rozwijanie przez nie nieefektywnych norm spotkałoby się bowiem $\mathrm{z}$ ich porzuceniem przez podmioty niezadowolone $\mathrm{z}$ ich rozstrzygnięć na rzecz konkurencyjnych instytucji ${ }^{42}$.

Konkurencja charakteryzująca klasyczne common law z czasem zaczęła jednak ulegać ograniczaniu. Proces ten był złożony, długotrwały i ściśle powiązany z politycznym umacnianiem się władzy monarszej oraz poszukiwaniem przez nią nowych źródeł dochodów ${ }^{43}$. Do kluczowych wydarzeń w tym względzie na-

38 W. Holdsworth, A History of English Law, t. 1. Methuen 1956, s. 252-255.

39 E. P. Stringham, T. J. Zywicki, Rivalry and Superior Dispatch: An Analysis of Competing Courts in Medieval and Early Modern England, "Public Choice" 2011, t. 147, z. 3, s. 497-524.

40 A. Smith, Badania nad naturą i przyczynami bogactwa narodów, tłum. B. Jasińska, Warszawa 2007, t. 2, k. V, cz. 2, s. 374-378.

41 C. K. Rowley, The Common Law in Public Choice Perspective: A Theoretical and Institutional Critique, “Hamline Law Review" 1988-1989, z. 12, s. 355-384.

42 T. J. Zywicki, The Rise and Fall..., s. 39.

43 B. L. Benson, The Enterprise of Law. Justice Without the State, San Francisco 1990, s. 43-77; N. A. Curott, E. P. Stringham, The Rise of Government Law Enforcement in England, [w:] The Pursuit of Justice. Law and Economics of Legal Institutions, red. E. J. López, New York 2010, s. 19-36. 
leży zaliczyć reformację prowadzącą do podporządkowania instytucji kościelnych państwu i efektywnego wyeliminowania w XVI w. odrębnej jurysdykcji sądów eklezjalnych. Stopniowe inkorporowanie do common law norm lex mercatoria wskutek czego w XVII w. dochodzi w Anglii do niemal całkowitego zaniknięcia sądów kupieckich i targowych. Rozwój publicznego aparatu ścigania skutkujący stopniowym odchodzeniem od prywatnych mechanizmów egzekwowania prawa. Wprowadzenie w 1826 r. prawnego zakazu czerpania przez sędziów sądów common law indywidualnych korzyści z opłat sądowych (przy jednoczesnym dwukrotnym podniesieniu wysokości należnej im pensji, co miało stanowić rekompensatę utraconych dochodów). W końcu szereg reform instytucjonalnych zwieńczonych dwoma aktami z drugiej połowy XIX w. - Supreme Court of Judicature Act 1873 i Appellate Jurisdiction Act 1876 - wyraźnie określającymi właściwość rzeczową sądów oraz istniejącą między nimi hierarchię.

Badania prowadzone na gruncie ekonomicznej analizy prawa nie pozostawiają wątpliwości, iż wyeliminowanie konkurencji istniejącej między angielskimi sądami było jedną z kluczowych, obok wykształcenia się restrykcyjnej wersji doktryny stare decisis, przyczyn stopniowego ograniczania efektywności common law ${ }^{44}$. Czynniki te są przy tym ze sobą ściśle powiązane. Fakt, iż wspó1czesne rozumienie zasady precedensu ukształtowało się dopiero $\mathrm{w}$ XIX w. jest $\mathrm{w}$ dużej mierze konsekwencją policentryczności wczesnonowożytnego angielskiego systemu sądowego przejawiającej się krzyżowaniem się jurysdykcji i brakiem wyraźnie określonej hierarchii sądów ${ }^{45}$.

W świetle poglądów ekonomicznych Hayeka ${ }^{46}$ fakt, iż milczy on na temat roli, jaką w procesie rozwoju common law odegrała konkurencja pomiędzy sądami różnych jurysdykcji jest zaskakujący ${ }^{47}$. Jeszcze bardziej zaskakujące jest jednak to, iż nie dostrzega on negatywnych konsekwencji jej wyeliminowania. Tymczasem monocentryczny system sądów o ściśle określonej hierarchii, w dużo większym stopniu przypomina „socjalistyczną biurokrację", o której w swej napastliwej krytyce common law pisał G. Tullock, niż wyidealizowany system Hayeka, w którym sędziowie niczym przedsiębiorcy działający na rynku, rozstrzygając jednostkowe spory odkrywają zasady postępowania przyczyniające się do wzrostu ogólnego dobrobytu. Nie powinno być więc dla niego zaskakującym, iż system ten - co wykazują liczne badania prowadzone na gruncie ekonomicznej analizy prawa - jest podatny na te same problemy, z którymi borykają się legislatury - problem selekcji, agencji (principal-agent problem), korupcji, pogoni za rentą (rent-seeking), przechwycenia instytucji regulującej (regulatory capture) czy

$44 \quad$ T. J. Zywicki, The Rise and Fall..., passim.

45 D. Vong, op. cit., s. 323-332.

46 Zob. np. K. Kostro, Hayek kontra socjalizm. Debata socjalistyczna a rozwój teorii spoteczno-ekonomicznych Friedricha Augusta von Hayeka, Warszawa 2001, passim.

47 Hayek bardzo dobrze znał prace A. Smitha na ten temat więc jego milczenie nie może być uznane za wyraz braku odpowiedniej wiedzy. 
w końcu problem wiedzy (knowledge problem), któremu poświęcił on tak wiele uwagi w swych pracach ekonomicznych ${ }^{48}$.

IV. W świetle powyższych rozważań wydaje się, że właściwą podstawą dla projektowanej przez Hayeka liberalnej alternatywy dla systemów prawnych opartych na legislacji, jest nie tyle błędnie przez niego charakteryzowane klasyczne common law, lecz policentryczny system prawny, w którym konkuruje ze sobą wiele sądów o krzyżujących się jurysdykcjach, stosujących zwyczajowe normy postępowania "odkrywane” na gruncie praktyki orzeczniczej" ${ }^{49}$. Za tego rodzaju rozwiązaniem opowiadał się m.in. Bruno Leoni, którego praca Freedom and the Law, była jednym z głównych źródeł inspiracji dla myśli prawnej Hayeka $^{50}$. To właśnie temu wybitnemu włoskiemu teoretykowi prawa ${ }^{51}$ Hayek zawdzięczał ewolucyjne spojrzenie na common law, ideę „rynku prawa” oraz spostrzeżenie o występowaniu wysokiego stopnia zbieżności pomiędzy procesem odkrywania norm przez sędziów, a odkrywaniem cen przez przedsiębiorców ${ }^{52}$. Pomimo jednak niezaprzeczalnego wpływu Leoniego na poglądy autora Law, Legislation and Liberty, ten ostatni odrzucił normatywne postulaty włoskiego teoretyka poświęcając im raptem krótki przypis, w którym ograniczył się do stwierdzenia, iż ,jakkolwiek argumentacja [Leoni'ego] stanowi efektywne antidotum dla dominującej ortodoksji (...) nie przekonała mnie ona, iż możemy całkowicie obejść się bez legislacji, nawet na gruncie prawa prywatnego, które jest głównym obszarem jego zainteresowania"53.

W późniejszych swych pracach Hayek nie wracał już do tego problemu, odniósł się jednak do kwestii urynkowienia systemu prawa w wywiadzie udzielonym T. Hazelettowi w 1978 r. Stwierdził w nim, iż głównym problemem policentrycznych systemów prawnych jest brak efektywnego mechanizmu unifikacji prawa, bez którego - zdaniem Hayeka - nie jest możliwe funkcjonowanie dużych, heterogenicznych społeczności. „Sądzę, iż istnieje jeden przekonujący

$48 \quad$ R. Barnett, The Structure..., s. 244-248 oraz R. Neely, Why Court Don't Work, New York 1993, passim.

49 E. P. Stringham, T. J. Zywicki, Hayekian Anarchism, "Journal of Economic Behavior and Organization” 2011, t. 78, z. 3, s. 290-301. Rozważania na temat tego jak mógłby w praktyce funkcjonować taki system m.in. w R. Barnett, The Structure..., s. 284-299. Analizę historycznego przykładu takiego systemu przeprowadzoną z pozycji Hayekowskich zawiera praca C. B. Kerekes, C. R. Williamson, Discovering Law: Hayekian Competition in Medieval Iceland, "Griffith Law Review" 2012, t. 21, z. 2, s. 432-447. Ogólnie na temat idei policentryzmu w prawie W. Gogłoza, Policentryczny porząek konstytucyjny - zarys historii idei, [w:] Tendencje rozwojowe myśli politycznej i prawnej, red. M. Maciejewski, M. Marszał, M. Sadowski, Wrocław 2014, s. 345-361.

50 B. Leoni, Freedom and the Law, wyd. 2, Los Angeles 1972, s. 20-24.

51 Na temat poglądów prawnych Leoniego i ich recepcji zob. P. H. Aranson, Bruno Leoni in Retrospect, „Harvard Journal of Law and Public Policy” 1988, t. 11, z. 3, s. 661-711 oraz L. P. Liggio, T. G. Plamer, Freedom and the Law: A Comment on Professor Arnarson's Article, "Harvard Journal of Law and Public Policy" 1988, t. 11, z. 3, s. 713-725.

52 Zob. korespondencję między Hayekiem a Leonim cytowaną w P. J. Boettke, R. A. Candela, Rivalry, Polycentricism, and Institutional Evolution, "George Mason University Working Paper in Economics" 2014, n. 15-25, s. 12.

53 F. A. Hayek, Law, Legislation... t. 1, s. 168, przyp. 35. 
powód, dla którego nie powinno się pozostawiać prawa dobrowolnej ewolucji - funkcjonowanie wielkiego społeczeństwa ${ }^{54}$ jest uzależnione od występowania w nim gwarancji, iż dowolna osoba, którą spotykasz na danym terytorium podlega temu samemu systemowi zasad prawa. W przeciwnym wypadku twoje kontakty musiałyby ograniczać się wyłącznie do osób, które już znasz. Wprowadzenie w życie postulatów niektórych współczesnych [zwolenników policentryzmu prawnego], zgodnie z którymi jedno stowarzyszenie może zgodzić się co do obowiązywania jednego prawa, inne zaś innego, doprowadziłoby do sytuacji, w której niemal niemożliwym byłoby zawieranie umów z obcymi osobami. [Z tego względu], dla każdego danego terytorium powinno istnieć zunifikowane prawo, to zaś może istnieć, tylko tam, gdzie podlega ono egzekucji przez państwo" ${ }^{\prime 55}$.

W przeciwieństwie zatem do zwolenników całkowitego urynkowienia systemu prawnego ${ }^{56}$ Hayek uznawał, iż choć samo prawo jest fenomenem społecznym o emergentnym charakterze, jego stosowanie i egzekucja winno ściśle podlegać państwu. Maksymalnie zdecentralizowanemu i o ograniczonych uprawnieniach, ale mającemu legalny monopol w zakresie tworzenia, stosowania i egzekucji norm prawnych. Tylko taki system jest bowiem, jego zdaniem, możliwy do pogodzenia z wymogiem powszechności i jednolitości prawa, będącego warunkiem sine qua non dla funkcjonowania „wielkiego społeczeństwa”. W jego „,konstytucji wolności” rolą sędziów jest odkrywanie na gruncie utrwalonych zachowań społecznych norm służących ogólnemu dobrobytowi (nomos), rolą legislatury ich okazjonalne korygowanie (gdy przestaną one odpowiadać rzeczywistości społecznej lub zaczną się rozwijać w kierunku uwzględniającym wyłącznie interesy partykularnych grup interesu), a zadaniem władzy wykonawczej ich egzekwowanie w szybki, bezstronny i ekonomicznie efektywny sposób.

Także i w stosunku do tego poglądu Hayeka, odpowiadającego w dużej mierze postulatom innych klasycznych liberałów odwołujących się do angloamerykańskich tradycji prawnych, można jednak zgłosić szereg wątpliwości, posiłkując się przy tym jego własnymi analizami o charakterze opisowo-wyjaśniającym i predykcyjnym. Spośród licznych problemów, które da się zidentyfikować w odniesieniu do normatywnych postulatów Hayeka na gruncie wniosków wynikających z przeprowadzonych przez niego badań, za najważniejsze należy uznać problemy wiedzy i bodźców, jakim podlegają w monocentrycznym systemie prawnym sędziowie i legislatorzy. Jak bowiem słusznie

$54 \quad$ Hayek używa tego terminu w znaczeniu nadanym mu wcześniej przez A. Smitha i podobnym do koncepcji „społeczeństwa otwartego” K. Poppera. Zob. idem, Law, Legislation..., t. 1, s. 148, przyp. 11.

55 E. Graver, Axel Leijonhufvud, L. Rosten, J. High, J. Buchanan, R. Bork, T. Hazlett, A. A. Alchian, R. Chitester, Nobel Prize Winning Economist Friedrich A. von Hayek - Oral History, Los Angeles 1983, s. 348 .

56 Zob. np. D. D. Friedman, The Machinery of Freedom. Guide to a Radical Capitalism, wyd. 3, New York 2014, s. 105-160; B. L. Benson, To Serve and Protect. Privatization and Community in Criminal Justice, New York 1998, passim; E. P. Stringham, Private Governance. Creating Order in Economic and Social Life, Oxford 2015, passim. 
zauważają E. P. Stringham i T. J. Zywicki, struktura instytucjonalna, jaką Hayek obrał dla swej ",konstytucji wolności” nie gwarantuje, ani, że będą oni jedynie "odkrywali" prawo, a nie tworzyli je według własnego uznania i bez oparcia na konwencjach społecznych, ani też, że sprawując swoje funkcje będą się kierowali interesem ogółu, a nie własnym i/lub zorganizowanych grup nacisku ${ }^{57}$.

$\mathrm{W}$ odniesieniu do pierwszego $\mathrm{z}$ wymienionych problemów - problemu wiedzy - należy zwrócić uwagę na kluczową różnicę pomiędzy odkrywaniem akceptowalnych cen przez przedsiębiorców działających na rynku a odkrywaniem przez sędziów właściwych norm zachowania w drodze rozstrzygania partykularnych sporów. Konstruując analogię między tymi procesami (patrz punkt I) Hayek wydaje się nie uwzględniać faktu, iż przedsiębiorcy na rynku podlegają konkurencji, a podjęte przez nich decyzje znajdują odzwierciedlenie w rachunku zysków i strat, wysokości cen, relacji popytu do podaży. Dzięki tym informacjom zwrotnym każdy $\mathrm{z}$ nich $\mathrm{z}$ osobna jest $\mathrm{w}$ stanie określić skalę sukcesu bądź niepowodzenia swojego przedsięwzięcia, ergo stopień zaspokojenia potrzeb klientów, zaś rynek, rozumiany, jako ogół działających na nim podmiotów, dokonać efektywnej alokacji zasobów. W monocentrycznym systemie wymiaru sprawiedliwości, za którym opowiada się Hayek sędziowie nie podlegają żadnemu $\mathrm{z}$ tych mechanizmów. W przeciwieństwie do opisywanych $\mathrm{w}$ poprzednim punkcie sądów funkcjonujących we wczesnonowożytnej Anglii, ich działalność nie spotyka się z konkurencją, a ich decyzje nie znajdują odzwierciedlenia $\mathrm{w}$ informacjach zwrotnych porównywalnych do rachunku strat i zysków. Strony sporów pozbawione są możliwości wyboru sądu opartych na takich kryteriach, jak np. czas oczekiwania na rozstrzygnięcie, sprawność procedowania, poziom sformalizowania procedury, bezstronność osoby orzekającej, czy posiadanie przez nią specjalistycznej wiedzy, a ich ewentualne przeszłe niekorzystne doświadczenia $\mathrm{z}$ danym sądem, czy negatywne opinie pozyskane na jego temat od innych osób pozbawione są znaczenia. Liczba rozpatrywanych przez dany sąd spraw oraz wysokość wpływających do jego kasy opłat sądowych nie ma w tym przypadku żadnego związku z jego reputacją i poziomem satysfakcji stron, nie może zatem stanowić podstawy dla oceny efektywności orzeczeń. Bliższą analogią w tym względzie wydaje się zatem gospodarka centralnie planowana, która, jak wykazywał Hayek w szeregu swych prac ekonomicznych, z powodu braku mechanizmu efektywnej utylizacji rozproszonej wiedzy, jest instytucjonalnie niezdolna do identyfikowania rzeczywistych potrzeb, a tym samym i właściwego rozdysponowania ograniczonych zasobów ${ }^{58}$. Nie wskazując mechanizmów, które miałyby skutecznie zastąpić konkurencję i system cenowy w obszarze prawa, Hayek naraża postulowany przez siebie monocentryczny system sądownictwa, na ten sam zarzut, który stawia gospodarkom planowym.

57 E. P. Stringham, T. J. Zywicki, op. cit., s. 295-301.

58 Zob. K. Kostro, op. cit., passim. 
Także postulat Hayeka, by prawo sędziowskie podlegało korygującej kontroli ze strony legislatury mającej dbać o to, by rozwijało się ono $\mathrm{w}$ zgodzie z oczekiwaniami społecznymi nie stanowi rozwiązania dla problemu wiedzy, a jedynie przenosi go na wyższy poziom. Członkowie ciała ustawodawczego również nie podlegają mechanizmowi cenowemu, a istniejąca między nimi konkurencja (o głosy wyborców), jest jedynie dalekim echem tej rynkowej. Różnica między rywalizacją zachodzącą pomiędzy przedsiębiorcami a kandydatami jest szczególnie wyraźna, gdy patrzymy na nią z perspektywy osób, o których pieniądze/poparcie oni zabiegają. Na rynku jednostki samodzielnie dokonują wyborów, a ich decyzje odzwierciedlają ich własne preferencje. Głos wyborcy tymczasem jest jednym $z$ wielu (ulega agregacji) i samodzielnie żaden $z$ nich nie jest w stanie przesądzić o wyniku wyborów. $Z$ tego też względu, w przeciwieństwie do konsumenta, wyborca nie otrzymuje tego, co sam chce, tylko, to czego chce dla niego większość osób biorących udział w głosowaniu. O ile zatem $\mathrm{w}$ tym pierwszym przypadku w interesie każdego indywidualnego konsumenta jest poszukiwanie możliwie najlepszej oferty spośród dostępnych na rynku (zysk odniesiony za sprawą dokonania właściwego wyboru zniweluje koszty porównywania dostępnych alternatyw), o tyle $\mathrm{w}$ drugim inwestycja $\mathrm{w}$ wiedzę (studiowanie programów wyborczych, analizowanie zachowań politycznych kandydatów) nie przyniesie praktycznych korzyści jednostkowych (z uwagi na bardzo małe prawdopodobieństwo, iż głos indywidualnego wyborcy okaże się decydującym, koszty, jakie poniesie on na poszerzanie swojej wiedzy politycznej niemal na pewno nie zwrócą się). Zgodnie z powyższą logiką - popartą licznymi badaniami empirycznymi - najlepsze na co możemy liczyć w odniesieniu do wyborców to, że większość z nich pozostanie "racjonalnymi ignorantami” w obszarze polityki ${ }^{59}$. „Najlepsze”, gdyż jak wykazują analizy B. Caplana, statystyczny członek elektoratu dokonując swych wyborów politycznych kieruje się nie tyle ignorancją (brakiem wiedzy), co systematycznym błędami poznawczymi (systematic bias) - w kluczowych obszarach dla funkcjonowania wspó1czesnych społeczeństw, poglądy przeciętnego wyborcy plasują się niemal na przeciwległym biegunie w stosunku do opinii eksperckich ${ }^{60}$. Politycy zabiegający o głosy wyborcze muszą wszelako uwzględniać te poglądy w swych programach. Paradoksalnie zatem (i wbrew utartemu przekonaniu opinii publicznej) współczesne demokracje borykają się z problemem niskiej satysfakcji elektoratu nie dlatego, że politycy "nie słuchają wyborców”, lecz dlatego, że „słuchają ich aż nadto" ${ }^{\prime \prime}$. Hayek słusznie zatem stara się ograniczyć zakres uprawnionych obszarów działania legislatury, nie przedstawia jednak żadnego mechanizmu, który miałby zagwarantować, iż jej członkowie będą w stanie lepiej niż

\footnotetext{
59 A. Downs, An Economic Theory of Democracy, New York 1957, s. 244-271.

60 B. Caplan, Systematically Biased Beliefs About Economics: Robust Evidence of Judgemental Anomalies from the Survey of Americans and Economists on the Economy, "Economic Journal" 2002, t. 112, z. 479, s. $433-458$.

61 Idem, The Myth of the Rational Voter: Why Democracies Choose Bad Policies, Princeton 2007, passim.
} 
sędziowie identyfikować normy służące ogólnemu dobrobytowi i porządkowi zbudowanemu na pokojowych relacjach jednostek.

Drugim zgłaszanym wcześniej problemem normatywnej strony analiz Hayeka jest kwestia bodźców, jakim będą podlegać sędziowie w postulowanym przez niego monocentrycznym systemie prawnym. Autor Law Legislation and Liberty ma jednoznaczną odpowiedź na pytanie "co powinni robić sędziowie?" - wspierać konwencje społeczne sprzyjające dobrobytowi i współpracy, milczy jednak w sprawie innego bezpośrednio powiązanego $\mathrm{z}$ tą kwestią zagadnienia, „dlaczego wydając orzeczenia mieliby oni kierować się preferencjami Hayeka, a nie własnymi bądź osób trzecich?"62 Ochrona wolności i stwarzanie warunków do wzrostu dobrobytu są szeroko podzielanymi wartościami, ale nie jedynymi funkcjonującymi w społeczeństwie i niekoniecznie najpopularniejszymi w środowiskach prawniczych. Dlaczego sędziowie nie mieliby preferować np. Rawlsowskiej bezstronności (fairness) ponad Hayekowską wolność, skoro w anglosaskiej doktrynie prawa, ta pierwsza jest znacznie bardziej popularna od tej drugiej? ${ }^{63}$ Co istotniejsze, wartości o charakterze ogólnym, ścierają się często z indywidualnymi potrzebami, oczekiwaniami i ambicjami sędziów. Jak bowiem słusznie zauważył jeden z pionierów i najwybitniejszych przedstawicieli ekonomicznej analizy prawa Richard Posner (notabene sam będący sędzią), członkowie składów orzekających, tak jak wszyscy inni racjonalni aktorzy, dążą do maksymalizowania użyteczności. Oznacza to, że w swej praktyce orzeczniczej mogą oni kierować się nie tyle ogólnymi wartościami, co partykularnymi interesami: chęcią wzmocnienia pozycji własnej, sądu lub środowiska sędziowskiego, osiągnięciem uznania w oczach innych sędziów, mediów czy szerszych kręgów społecznych, odniesieniem korzyści finansowych, promocją politycznej agendy ${ }^{64}$. W policentrycznym systemie prawnym zjawisko to jest ograniczane przez konkurencję istniejącą między sądami (vide rozważania z poprzedniego punktu dotyczące konsekwencji „,współzawodnictwa” między sądami wczesnonowożytnej Anglii), w modelu proponowanym przez Hayeka taki mechanizm nie istnieje. Brak ten jest niezwykle istotny, gdyż w praktyce o tym, jak orzekają sędziowie w znacznie większym stopniu decyduje struktura instytucjonalna systemu wymiaru sprawiedliwości, niż preferencje nawet najwybitniejszych przedstawicieli teorii i doktryny prawa ${ }^{65}$.

Co jednak z obawami Hayeka, iż prawo policentryczne nie będzie dostatecznie zunifikowane, by sprostać wymogom dużych heterogenicznych

62 C. K. Rowley, op. cit., s. 372. Zob. też. J Hasnas, Hayek, the Common Law..., s. 104-105.

63 J. Lindgren, Measuring Diversity: Law Faculties in 1997 and 2013, „Northwestern Law \& Econ Research Paper" No. 15-07 oraz N.Q. Rosenkranz, Intellectual Diversity in the Legal Academy, "Harvard Journal of Law \& Public Policy" 2014, t. 37, z.1, s. 137-143.

${ }_{64}$ R. A. Posner, What Do Judges and Justices Maximize? (The Same Thing Everybody Else Does), "Supreme Court Economic Review" 1993, t.3, z.1, s. 1-41.

65 B. Caplan, E.P. Stringham, Privatizing the Adjudication of Disputes, "Theoretical Inquiries in Law" 2008, t. 9 , z. 3, s. 503-528. 
społeczeństw? W pierwszej kolejności należy zaznaczyć, iż wbrew temu co zdaje się sugerować autor Law Legislation and Liberty policentryzm nie jest nową, niesprawdzoną koncepcją teoretyczną garstki współczesnych radykalnych liberałów, lecz historycznym doświadczeniem krajów zaliczanych do okcydentalnej tradycji prawnej. Przed ukształtowaniem się państw narodowych współistnienie na tym samym terenie wielu konkurujących ze sobą jurysdykcji było w Europie powszechnym zjawiskiem i dziś jest uznawane za differentia specifica kontynentalnej kultury prawnej okresu średniowiecza i wczesnonowożytnego ${ }^{66}$. Opisywany w poprzednim punkcie przykład policentryzmu funkcjonującego w Anglii dowodzi przy tym, iż nakładanie się na siebie różnych systemów prawnych nie musi wcale prowadzić do „bałkanizacji” prawa i ograniczenia kręgu podmiotów, z którymi jednostka może nawiązać relacje umowne wyłącznie do grona znanych jej osób, czego obawiał się Hayek. Wręcz przeciwnie, we współczesnej literaturze przedmiotu podkreśla się, iż policentryzm panujący w Europie Zachodniej w okresie wczesnonowożytnym był jednym z najistotniejszych czynników umożliwiających dynamiczny rozwój kapitalizmu ${ }^{67}$. Z kolei historycy prawa upatrują w nim głównego mechanizmu wzajemnego ograniczania się władzy świeckiej i kościelnej, a w konsekwencji źródło wolności politycznej Europejczyków ${ }^{68}$.

Stwierdzenie Hayeka, jakoby podleganie przez różne osoby różnym systemom prawnym uniemożliwiało im nawiązywanie wiążących umów pozostaje też w oczywistej sprzeczności z realiami współczesnego świata, na co najlepszym dowodem jest stale powiększający się wolumen międzynarodowej wymiany gospodarczej. Z danych World Trade Organization wynika, iż podmioty żyjące pod rządami różnych systemów prawnych wymieniły między sobą w 2013 r. (ostatnim, dla którego w chwili przygotowywania artykułu istnieją kompleksowe analizy) towary i usługi o wartości 18,301 miliardów USD ${ }^{69}$. Co więcej, międzynarodowa wymiana gospodarcza odbywa się nie tylko przy braku ponadnarodowego jednolitego prawa zobowiązań, ale także przy jedynie minimalnym wsparciu ze strony organów wykonawczych krajów, z których pochodzą partnerzy handlowi ${ }^{70}$. Do czasu wejścia w życie konwencji nowojorskiej o uznawaniu i wykonywaniu zagranicznych orzeczeń arbitrażowych z 10 czerwca 1958 r. ${ }^{71}$ przedsiębiorcy prowadzący transgraniczne interesy pozbawieni byli efektywnych mechanizmów publicznej egzekucji orzeczeń zapadłych

66 H. Spruyt, The Sovereign State and Its Competitors: An Analysis of Systems Change, Princeton 1996, s. 34 in.

67 N. Rosenberg, L. E. Jr. Birdzell, Historia kapitalizmu, Kraków 1994, s. 97-101.

68 H. J. Berman, Prawo i rewolucja. Ksztattowanie się zachodniej tradycji prawnej, Warszawa 1995, s. 23- 24.

69 World Trade Organization, International Trade Statistics 2014, Geneva 2104, dokument elektroniczny dostępny pod adresem https://www.wto.org/english/res_e/statis_e/its2014_e/its2014_e.pdf (05.10.2015).

70 P. T. Leeson, How Important is State Enforcement for Trade?, "American Law and Economics Review" 2008, t. 10, z. 1, s. 61-89.

71 Dz. U. 1962 nr 9, poz. 41. 
w związku z międzynarodowymi sporami handlowymi. W praktyce stan ten oznaczał, iż wykonywanie zobowiązań umownych pomiędzy partnerami z różnych krajów opierało się głównie na reżimie powtarzalnych transakcji i sankcjach rozproszonych, a mimo to wartość międzynarodowego obrotu towarowego już na pięć lat przed wejściem w życie wyżej wspomnianej konwencji wynosiła prawie 85 miliardów USD. Także obecnie, gdy suma ta jest kilkunastokrotnie wyższa, zdecydowana większość międzynarodowych transakcji gospodarczych przebiega w sposób bezkonfliktowy, a stosunkowo nieliczne przypadki sporów są skutecznie rozstrzygane na drodze prywatnego arbitrażu ${ }^{72}$, prowadzonego z użyciem norm i procedur sięgających swymi korzeniami do spontanicznie powstałego policentrycznego systemu średniowiecznego prawa kupieckiego (lex mercatoria) ${ }^{73}$. Hayek myli się więc nie tylko co do tego, że zawieranie umów przez nieznające się osoby wymaga podlegania przez nie temu samemu systemowi prawa, ale także co do tego, że pokojowa współpraca jednostek jest uzależniona od egzekwowania orzeczeń przez państwo ${ }^{74}$.

\section{Bibliografia}

Aranson P. H., Bruno Leoni in Retrospect, "Harvard Journal of Law and Public Policy" 1988 , t. 11 , z. 3, s. 661-711.

Baker J. H., The Common Law Tradition: Lawyers, Books and the Law, London 2000.

Barnett R., The Structure of Liberty. Justice and the Rule of Law, Oxford 2000.

Barry N., The Tradition of Spontaneous Order, "Literature of Liberty" 1982, t. 5, z. 2, s. 7-58.

Benson B. L., The Spontaneous Evolution of Commercial Law, "Southern Economic Journal" 1989 , t. 55, z. 3, s. 644-661.

Benson B. L., The Enterprise of Law. Justice Without the State, San Francisco 1990.

Benson B. L., To Serve and Protect. Privatization and Community in Criminal Justice, New York 1998.

Berman H., The Origins of Historical Jurisprudence: Coke, Selden, Hale, "The Yale Law Journal" 1994, t. 103, z. 7, s. 1651-1738.

Berman H. J., Kaufman C., The Law of International Commercial Transactions (Lex Mercatoria), "Harvard International Law Review" 1978, t. 19, z. 1, s. 221-277.

72 Y. Dezalay, B. G. Garth, Dealing in Virtue: International Commercial Arbitration and the Construction of a Transnational Legal Order, Chicago 1998.

73 B. L. Benson, The Spontaneous Evolution of Commercial Law, "Southern Economic Journal" 1989, t. 55, z. 3, s. 644-661; P. R. Milgrom, D. C. North, B. R. Weingast, The Role of Institutions in the Revival of Trade: The Medieval Law Merchant, Private Judges, and the Champagne Fairs, "Economics and Politics" 1990, t. 2, z. 1, s. 1-23; H.J. Berman, C. Kaufman, The Law of International Commercial Transactions (Lex Mercatoria), "Harvard International Law Review" 1978, t. 19, z. 1, s. 221-277.

74 Zob. P. T. Leeson, Do Markets Need Government? [w:] The Legal Foundations of Free Markets, red. S. F. Copp, London 2008, s. 42-64 i inne przywoływane tam pozycje tego autora. 
Block W., Defending the Undefendable. The Pimp, Prostitute, Scab, Slumlord, Libeler, Moneylender, and Other Scapegoats in the Rogue's Gallery of American Society, Auburn 2008.

Boettke P. J., The Theory of Spontaneous Order and Cultural Evolution in the Social Theory of F.A. Hayek, “Cultural Dynamics” 1990, t. 3, z. 1, s. 61-81.

Boettke P. J., Candela R. A., Rivalry, Polycentricism, and Institutional Evolution, "George Mason University Working Paper in Economics" 2014, n. 15-25.

Boudreaux D. J., The Essential Hayek, Vancouver 2014.

Bryan M., Early English Law Reporting, “University of Melburn Collections” 2009, z. 4, s. 45-50.

Butler E., Hayek: His Contribution to the Political and Economic Thought of Our Time, London 1983.

Caplan B., Systematically Biased Beliefs About Economics: Robust Evidence of Judgemental Anomalies from the Survey of Americans and Economists on the Economy, "Economic Journal" 2002, t. 112, z. 479, s. 433-458.

Caplan B., The Myth of the Rational Voter: Why Democracies Choose Bad Policies. Princeton 2007.

Caplan B., Stringham E. P., Privatizing the Adjudication of Disputes, "Theoretical Inquiries in Law" 2008, t. 9, z. 3, s. 503-528.

Christiansen G. B., Law as a Discovery Procedure, "Cato Journal" 1990, t. 9, z. 3, s. 497530 .

Curott N. A., Stringham E. P., The Rise of Government Law Enforcement in England, [w:] The Pursuit of Justice. Law and Economics of Legal Institutions, red. E. J. López, New York 2010, s. 19-36.

Dezalay Y., Garth B. G., Dealing in Virtue: International Commercial Arbitration and the Construction of a Transnational Legal Order, Chicago 1998.

Dizerga G., Outlining a New Paradigm, “Cosmos \& Taxis. Studies in Emergent Order and Organization", 2013, t.1, z. 1, s. 3-19.

Downs A., An Economic Theory of Democracy, New York 1957.

Friedman D. D., The Machinery of Freedom. Guide to a Radical Capitalism, wyd. 3, New York 2014.

Gogłoza W., Policentryczny porządek konstytucyjny - zarys historii idei, [w:] Tendencje rozwojowe myśli politycznej i prawnej, red. M. Maciejewski, M. Marszał, M. Sadowski, Wrocław 2014, s. 345-361.

Gogłoza W., Analityczny anarchizm - cele, przedmiot i metody badań empirycznych nad stanami natury, [w:] Myślenie o polityce i prawie - przedmiot, metoda, perspektywa, red. Barwicka-Tylek, A. Czarnecka, M. Jaskólski, J. Malczewski,Warszawa 2015, s. 209-232.

Graver E., Leijonhufvud A., Rosten L., High J., Buchanan J., Bork R., Hazlett T., Alchian A. A., Chitester R., Nobel Prize Winning Economist Friedrich A. von Hayek - Oral History, Los Angeles 1983. 
Hayek F. A., The Use of Knowledge in Society, "American Economic Review" 1945, t. 35, z. 4, s. 519-530 .

Hayek F. A. von, Kinds of Order in Society, "New Individualist Review” 1964, t. 3, z. 2, s. $457-466$.

Hayek F. A. von, Law, Legislation and Liberty. A New Statement of the Liberal Principles of Justice and Political Economy, London 1998.

Hasnas J., Hayek, the Common Law, and Fluid Drive, "New York University Journal of Law and Liberty" 2005, t.1, z.1, s. 79-110.

Holdsworth W., A History of English Law, t. 1. Methuen 1956.

Hoppe H. H., F. A. Hayek on Government and Social Evolution: A Critique, "The Review of Austrian Economics" 1994, t. 7, z. 1, s. 67-93.

Horowitz S., From Smith to Menger to Hayek: Liberalism in the Spontaneous-Order Tradition, "The Independent Review" 2001, t. 6, z. 1, s. 81-97.

Kerekes C. B., Williamson C. R., Discovering Law: Hayekian Competition in Medieval Iceland, "Griffith Law Review" 2012, t. 21, z. 2, s. 432-447.

Klerman D., Jurisdictional Competition and the Evolution of the Common Law, "University of Chicago Law Review" 2007, t. 74, z.4, s. 1179-1226.

Kostro K., Hayek kontra socjalizm. Debata socjalistyczna a rozwój teorii społeczno-ekonomicznych Friedricha Augusta von Hayeka, Warszawa 2001.

Leeson P. T., Do Markets Need Government? [w:] The Legal Foundations of Free Markets, red. S. F. Copp, London 2008, s. 42-64.

Leeson P. T., How Important is State Enforcement for Trade?, "American Law and Economics Review" 2008, t. 10, z. 1, s. 61-89.

Leoni B., Freedom and the Law, wyd. 2, Los Angeles 1972.

Liggio L. P., Plamer T. G., Freedom and the Law: A Comment on Professor Arnarson's Article, "Harvard Journal of Law and Public Policy" 1988, t. 11, z. 3, s. 713-725.

Lindgren J., Measuring diversity: Law Faculties in 1997 and 2013, “Northwestern Law \& Econ Research Paper" No. 15-07.

Milgrom P. R., North D. C., Weingast B. R., The Role of Institutions in the Revival of Trade: The Medieval Law Merchant, Private Judges, and the Champagne Fairs, "Economics and Politics" 1990, t. 2, z. 1, s. 1-23.

Neely R., Why Court Don't Work, New York 1993.

O'Drisco G. P. 11, Economics as a Coordination Problem: The Contributions of Friedrich A. Hayek, Kansas City 1977.

Plucknett T. F. T., A Concise History of the Common Law, Indianapolis 2010.

Pocock J. G. A., The Ancient Constitution and the Feudal Law: A Study of English Historical Thought in the Seventeenth Century, Cambridge 1987.

Posner R. A., What Do Judges and Justices Maximize? (The Same Thing Everybody Else Does), "Supreme Court Economic Review" 1993, t.3, z.1, s. 1-41.

Rosenkranz N. Q., Intellectual Diversity in the Legal Academy, "Harvard Journal of Law \& Public Policy" 2014, t. 37, z.1, s. 137-143. 
Rothbard M. N., The Present State of Austrian Economics, "Journal des Economistes et des Etudes Humaines" 1995, t. 6, z. 1, s. 43-89.

Rowley C. K., The Common Law in Public Choice Perspective: A Theoretical and Institutional Critique, "Hamline Law Review" 1988-1989, z. 12, s. 355-384.

Salerno, Ludwig von Mises as Social Rationalist, "The Review of Austrian Economics J. T." 1990, t. 4, z. 1, s. 26-54.

Sandefur T., Some Problems with Spontaneous Order, "The Independent Review" 2009, t. 14, z. 1, s. 5-25.

Smith A., Badania nad natura i przyczynami bogactwa narodów, tłum. B. Jasińska, Warszawa 2007.

Smith V. L., Racjonalność w ekonomii, Warszawa 2013.

Spruyt H., The Sovereign State and Its Competitors: An Analysis of Systems Change, Princeton 1996.

Steele D. R., Hayek's Theory of Cultural Grup Selection, "The Journal of Libertarian Studies" 1987, t. 8, z. 2, s. 171-195.

Stringham E. P., Private Governance. Creating Order in Economic and Social Life, Oxford 2015.

Stringham E. P., Zywicki T. J., Rivalry and Superior Dispatch: An Analysis of Competing Courts in Medieval and Early Modern England, "Public Choice" 2011, t. 147, z. 3, s. $497-524$.

Stringham E. P., Zywicki T. J., Hayekian Anarchism, "Journal of Economic Behavior and Organization" 2011, t. 78, z. 3, s. 290-301.

Sztaba S., Aktywne poszukiwanie renty. Teoria, przykłady historyczne, przejawy w polskiej gospodarce, Warszawa 2002.

Tullock G., The Case Against the Common Law, [w:] The Selected Works of Gordon Tullock: Law and Economics, red. C. K. Rowley, t. 9, Indianapolis 2005.

Zywicki T. J., The Rise and Fall of Efficiency in the Common Law: A Supply-Side Analysis, "George Mason University Law and Economics Working Paper Series" n. 02-21.

Zywicki T. J., Spontaneous Order and the Common law: Gordon Tullock's Critique, "Public Choice" 2008, z. 135, s. 35-53.

Zywicki T. J., Sanders A. B., Posner, Hayek, and the Economic Analysis of Law, "Iowa Law Review" 2008, z. 93, s. 559-604.

Vong D., Biding Precedent and English Judicial Law-Making, "Jura Falconis" 1984-1985, t. 21, z. 3, s. 318-346. 